\title{
CONSEQUENCES OF Cd AND CHICKEN MANURE ON GROWTH AND ON SOME NUTRIENT CONTENTS OF SPINACH PLANTS (SPINACIA OLERACEA L.)
}

\author{
CELIK, H. $^{{ }^{*}}-$ KUNENE, S. S. ${ }^{2}$ \\ ${ }^{1}$ Faculty of Agriculture, Department of Soil Science and Plant Nutrition, Bursa Uludag \\ University, Bursa, Turkey \\ ${ }^{2}$ Institute of Natural and Applied Science, Department of Soil Science and Plant Nutrition, \\ Bursa Uludag University, Bursa, Turkey \\ ${ }^{*}$ Corresponding author \\ e-mail: hcelik@uludag.edu.tr; phone: +90-224-294-1539 \\ (Received 21 $1^{\text {st }}$ Jan 2021; accepted $14^{\text {th }}$ May 2021)
}

\begin{abstract}
We aimed to determine the impact of cadmium (Cd) and chicken manure on dry weight (dw), $\mathrm{Cd}$ and some nutrient element concentrations of spinach plants, as well as their uptake. Cadmium doses of 0,10 , and $20 \mathrm{mg} \mathrm{kg}^{-1}$, and $0,5000,10000$, and $20000 \mathrm{~kg} \mathrm{ha}^{-1}$ chicken manure (CM) were applied to the soil in greenhouse conditions under randomized plots with three replicates. Cd doses elevated $\mathrm{N}, \mathrm{K}, \mathrm{Ca}, \mathrm{Mg}$, $\mathrm{Na}, \mathrm{Mg}$ and $\mathrm{Cd}$ concentrations and also $\mathrm{Cd}$ uptake, but decreased the dry weight and the up-taken amounts of nutrient elements. Because of the severe root degradation, Cd uptake was found high in the leaves rather than roots. Adding chicken manure, improved dry weight and elevated the up-taken amounts of nutrient elements $(\mathrm{p}<0.01)$. However, it was observed that the applications could not lower the $\mathrm{Cd}$ concentrations below the WHO limits. Due to the fact that the plant nutrient concentrations are within the limits of sufficiency and there are no signs of toxicity in the plants despite the high $\mathrm{Cd}$ content, it may cause people to consume these plants unaware of the high $\mathrm{Cd}$ content and deteriorate their health.
\end{abstract}

Keywords: antagonism, accumulator, health, heavy metals, toxicity

\section{Introduction}

In addition to the radioactive waste and sludge arising from today's industrial activities such as mining, energy and fuel production increasing with human population; due to the excessive use of chemical fertilizers, pesticides and irrigation with wastewater the natural distribution patterns and concentrations of heavy metals increase significantly (Dorak and Çelik, 2020; Qin et al., 2020).

Some heavy metal trace elements [iron $(\mathrm{Fe})$, zinc $(\mathrm{Zn})$, manganese $(\mathrm{Mn})$, copper $(\mathrm{Cu})$, molybdenum (Mo), nickel (Ni) and cobalt (Co)] affect the growth, development and physiological life functions of plants. Even though a limited amount of these elements are absolutely necessary, overdosing them and low amounts of many other heavy metals [arsenic (As), mercury $(\mathrm{Hg})$, cadmium $(\mathrm{Cd})$ and lead $(\mathrm{Pb})]$ outside this group can be toxic to plants. (Adesoye et al., 2014; Zhang et al., 2014; Chetan and Ami, 2015; Ali and Khan, 2018). It has been stated that the heavy metal levels above $100,000 \mu \mathrm{g} \mathrm{g}^{-1}$ in the soil disrupt the ecological balance and may increase the amounts in the plants grown on it and deteriorate many physiological properties such as water intake, germination, photosynthesis, membrane stability, stoma movements, transpiration, enzyme activity, protein synthesis, and hormonal balance so inhibit the vegetative growth and decrease the productivity of crops (Kabata-Pendias, 2011; Nazar et al., 2012; Chetan and Ami, 2015; Sun et al., 2015; Shaheen et al., 2016; Antoniadis et al., 2019; Qin et al., 2020). 
It causes not only a decrease in the yield and quality of the crops, but it may also cause some diseases due to the accumulation in living beings who consume these plants. In people exposed to high concentrations of heavy metals, it is reported that heavy metals can cause serious damage to the liver, kidney, lung and various vital organs in the human body by causing deterioration in blood composition and blood pressure, causing damage to central and mental processes and may adversely affect people's lives (Chetan and Ami, 2015; Shaheen et al., 2016; Ali and Khan, 2018; Antoniadis et al., 2019; Chen et al., 2019).

$\mathrm{Cd}$, which was one of the heavy metals considered as an environmental pollutant and has a maximum allowable concentration between $1-20 \mathrm{mg} \mathrm{kg}^{-1}$ in agricultural soils in various countries may accumulate in the soil by intensive and continuous use of phosphorus fertilizers (Kabata-Pendias, 2011). Due to high concentrations of cadmium in the soil and its mobility from the soil to roots and higher plant parts, cadmium may accumulate in plants and adversely affect human health through the food chain. (Chetan and Ami, 2015; Chen et al., 2019). Spinach is a widely consumed vegetable plant in recent years due to the higher constituents of vitamins and nutrients. However, as a hyper accumulator plant, it may not be safe for human consumption in terms of heavy metal and element content in soils contaminated with $\mathrm{Cd}$, as they can grow in normal appearance.

Lots of remediation strategies exists for metal contaminated soils, however these techniques were expensive and found not applicable for wide areas. In addition to phosphorite, zeolite, montmorillonite, some agricultural practices such as humic and organic matter have been tried to limit the mobility of heavy metals and prevent their uptake to plants (Kabata-Pendias, 2011; Hina et al., 2019). Kabata-Pendias (2011), stated that some of the soil properties including; CEC, clay minerals, $\mathrm{pH}$ affected amounts of carbonates, hydrous oxide metals, and also kind of organic matter affects heavy metal solubility in soils. In various studies, reduced mobility and uptake were also reported with the application of animal manure, crop residues and biosolids (Adhikari and Singh, 2008; Kumarpandit et al., 2017; Canal et al., 2018; Hina et al., 2019). Chicken manure having high nutrient element and increasing the aeration and water holding capacity of the soil, may also be used as a soil amendment material (Dikinya and Mufwanzala, 2010; Adesoye et al., 2014).

We conducted the research to determine the impact of $\mathrm{Cd}$ and chicken manure on dry weight, cadmium, some nutrient element concentrations and also their up-taken amounts in spinach used as a test plant, and to evaluate the ability of chicken manure preventing the damage of cadmium.

\section{Materials and Methods}

\section{Experimental location}

The greenhouse where the study was conducted, is in the Agricultural Research and Application Center of Bursa Uludag University in Turkey $\left(39^{\circ} 35^{\prime}, 40^{\circ} 40^{\prime}\right.$ and $28^{\circ} 10^{\prime}$, $\left.30^{\circ} 00^{\prime}\right)$.

\section{Experimental design}

We collected the soil sample used in the research from the depth of $0-20 \mathrm{~cm}$ at the field located at the Agricultural Research and Application Centre. Some soil properties are shown in Table 1. The soil had a clay texture and low lime content. Its' $\mathrm{pH}$ was 7.91. The 
soil had sufficient organic matter and has no problems with salt, nutrient elements and also heavy metals (Table 1).

Table 1. Some of the Soil Properties

\begin{tabular}{|c|c|c|c|}
\hline Properties & Amounts & Properties & Extractable Amounts \\
\hline Texture & Clay & Phosphorus (P), mg kg-1 & 14.51 \\
\hline Sand, $\%$ & 44.76 & Potassium (K), $\mathrm{mg} \mathrm{kg}^{-1}$ & 375.5 \\
\hline Silt, \% & 14.00 & Sodium (Na), $\mathrm{mg} \mathrm{kg}^{-1}$ & 175.6 \\
\hline Clay, \% & 41.24 & Calcium $(\mathrm{Ca}), \mathrm{mg} \mathrm{kg}^{-1}$ & 10048 \\
\hline $\mathrm{pH}(1: 2.5$ soil:water $)$ & 7.91 & Magnesium (Mg), $\mathrm{mg} \mathrm{kg}^{-1}$ & 390.2 \\
\hline $\mathrm{EC}, \mathrm{mS} \mathrm{cm}^{-1}$ & 0.53 & $\operatorname{Iron}(\mathrm{Fe}), \mu \mathrm{g} \mathrm{g}^{-1}$ & 12.49 \\
\hline $\mathrm{CaCO}_{3}, \%$ & 4.68 & Cupper $(\mathrm{Cu}), \mu \mathrm{g} \mathrm{g}^{-1}$ & 1.56 \\
\hline Organic matter, $\%$ & 2.21 & Zinc (Zn), $\mu \mathrm{g} \mathrm{g}^{-1}$ & 0.95 \\
\hline Total nitrogen $(\mathrm{N}), \%$ & 0.092 & Manganese (Mn), $\mu \mathrm{g} \mathrm{g}^{-1}$ & 31.64 \\
\hline Field capacity, \% & 23.57 & Boron (B), $\mu \mathrm{g} \mathrm{g}^{-1}$ & 0.65 \\
\hline & & Cadmium (Cd), $\mu \mathrm{g} \mathrm{g}^{-1}$ & 0.02 \\
\hline & & Lead $(\mathrm{Pb}), \mu \mathrm{g} \mathrm{g}^{-1}$ & 1.82 \\
\hline & & Chromium (Cr), $\mu \mathrm{g} \mathrm{g}^{-1}$ & 0.02 \\
\hline
\end{tabular}

Dried soil was passed through a $4 \mathrm{~mm}$ sieve and weighed $3.5 \mathrm{~kg}$ in polyethylene covered plastic pots having $20 \mathrm{~cm}$ in diameter and $18 \mathrm{~cm}$ deep. Three cadmium doses $(0$, 10 and $\left.20 \mathrm{mg} \mathrm{Cd} \mathrm{kg}^{-1}\right)$ in the form of solution as cadmium sulphate $\left(3 \mathrm{CdSO}_{4} .8 \mathrm{H}_{2} \mathrm{O}\right)$ (Extra pure, Merck, Germany), and four chicken manure (CM) doses (0, 5000, 10000 and $20000 \mathrm{~kg} \mathrm{CM} \mathrm{ha}^{-1}$ ) in a solid state were applied to the pots in randomized plots design with three replicates. Before planting, $50 \mathrm{mg} \mathrm{N} \mathrm{kg}$ as ammonium nitrate $\left(\mathrm{NH}_{4} \mathrm{NO}_{3}\right)$ (Extra pure, Merck, Germany), $40 \mathrm{mg} \mathrm{P} \mathrm{kg}^{-1}, 50 \mathrm{mg} \mathrm{K} \mathrm{kg}^{-1}$ as monopotassium phosphate $\left(\mathrm{KH}_{2} \mathrm{PO}_{4}\right)$ (Emprove, Merck, Germany) were added to the pots and incubated for 60 days. A pelleted chicken manure (Batısel-Yükseller company, Manisa/Turkey), which of its some properties were shown on Table 2 was used in the experiment.

Table 2. Some properties of the chicken manure*

\begin{tabular}{|c|c|c|c|}
\hline Properties & Amounts & Properties & Amounts \\
\hline $\mathrm{pH},(1: 2.5 \mathrm{w} / \mathrm{v})$ & 9.82 & Iron $(\mathrm{Fe}) \mathrm{g} \mathrm{kg}^{-1}$ & 8.84 \\
\hline $\mathrm{EC}, \mathrm{mS} \mathrm{cm} \mathrm{cm}^{-1}$ & 11.72 & Cupper $(\mathrm{Cu}) \mu \mathrm{g} \mathrm{g}^{-1}$ & 61.41 \\
\hline Organic matter, $\%$ & 42.45 & Zinc (Zn) $\mu \mathrm{g} \mathrm{g}^{-1}$ & 376.97 \\
\hline Nitrogen $(\mathrm{N}), \mathrm{g} \mathrm{kg}^{-1}$ & 13.89 & Manganese (Mn) $\mu \mathrm{g} \mathrm{g}^{-1}$ & 642.75 \\
\hline Phosphorus (P), $\mathrm{g} \mathrm{kg}^{-1}$ & 16.13 & Boron (B) $\mu \mathrm{g} \mathrm{g}^{-1}$ & 44.48 \\
\hline Sodium (Na), $\mathrm{g} \mathrm{kg}^{-1}$ & 4.55 & Cadmium (Cd) $\mu \mathrm{g} \mathrm{g}^{-1}$ & 0.22 \\
\hline Potassium (K), $\mathrm{g} \mathrm{kg}^{-1}$ & 23.35 & Lead $(\mathrm{Pb}) \mu \mathrm{g} \mathrm{g}^{-1}$ & 0.21 \\
\hline Calcium (Ca), $\mathrm{g} \mathrm{kg}^{-1}$ & 60.73 & Chromium ( $\mathrm{Cr} \mu \mathrm{g} \mathrm{g}^{-1}$ & 54.00 \\
\hline Magnesium (Mg), $\mathrm{g} \mathrm{kg}^{-1}$ & 7.49 & & \\
\hline
\end{tabular}

*Batısel-Yükseller Company, Manisa/Turkey

We planted five seeds of spinach (spinacia oleracea L. CV Reis F1) in each pot and after germination thinned to leave three plants. Field capacity of the soil was measured by graduated cylinder method (Tan, 1995). Throughout the experiment we tried to keep the soil in the pots at $70 \%$ of the field capacity by weighing the pots before watering and 
giving the water to the pots as much as the reduced amount. 45 days after the beginning of the experiment, the leaves were cut from the ground level and then the roots were also removed. Leaves and roots were transferred to the laboratory immediately, were washed in tap water and then with deionized water. The plant samples were dried to a constant weight in an air circulated oven (Nuve $\mathrm{KD} 400$, Turkey) at $70^{\circ} \mathrm{C}$, weighed and then were milled with $0.5 \mathrm{~mm}$ mesh size with laboratory mill (Foss CT 193 cyclotec, Denmark).

We applied a microwave oven (Berghof MWS 2, Germany) digestion to the ground samples using $6 \mathrm{~mL}(1: 1 \mathrm{v} / \mathrm{v})$ mixture of nitric acid $\left(\mathrm{HNO}_{3}\right)(65 \%$, Emplura, Merck) and hydrogen peroxide $\left(\mathrm{H}_{2} \mathrm{O}_{2}\right)$ (35\%, Emprove, Merck, Germany) (Celik et al., 2017). In order to determine the concentrations of $\mathrm{Cd}, \mathrm{P}, \mathrm{B}$ and $\mathrm{Mg}$ we used inductively coupled plasma-optical emission spectrometry (ICP-OES) (Perkin Elmer Optima 2100DV, USA) (Hansen et al., 2013). Concentrations of K, Ca and Na were determined by flame emission (Eppendorf Elex 6361; Hamburg, Germany) (Horneck and Hanson, 1998), total N by the Kjeldahl method (Buchi K-437, K-350; Buchi, Flawil, Switzerland) (Kacar, 2014). The up-taken amounts were calculated using the determined concentrations of the elements, and leaves and the roots dry weight (dw) values.

\section{Statistical analysis}

A computer programme (MINITAB 17.1.0.0 Minitab Inc., State College, Pennsylvania, USA) were used for the statistical analysis. All the data collected were subjected to analysis of variance. The treatment means were compared using the least significant difference (LSD) tests.

\section{Results and discussion}

\section{Effects of cadmium on dry weight amounts}

Statistically significant $(\mathrm{p}<0.01)$ leaf and root dry weight yield results were found with increasing application doses of cadmium to the soil. Increasing the doses of cadmium, negatively affected the dry weight yield of leaf and root of the plants and the least dry weight yield in leaves $(2.77 \mathrm{~g})$ and in roots $(0.52 \mathrm{~g})$ was determined at the highest application dose of cadmium $(\mathrm{Cd} 2)$ (Table 3).

Table 3. Effects of Cd and chicken manure on leaf and root dry weight of spinach

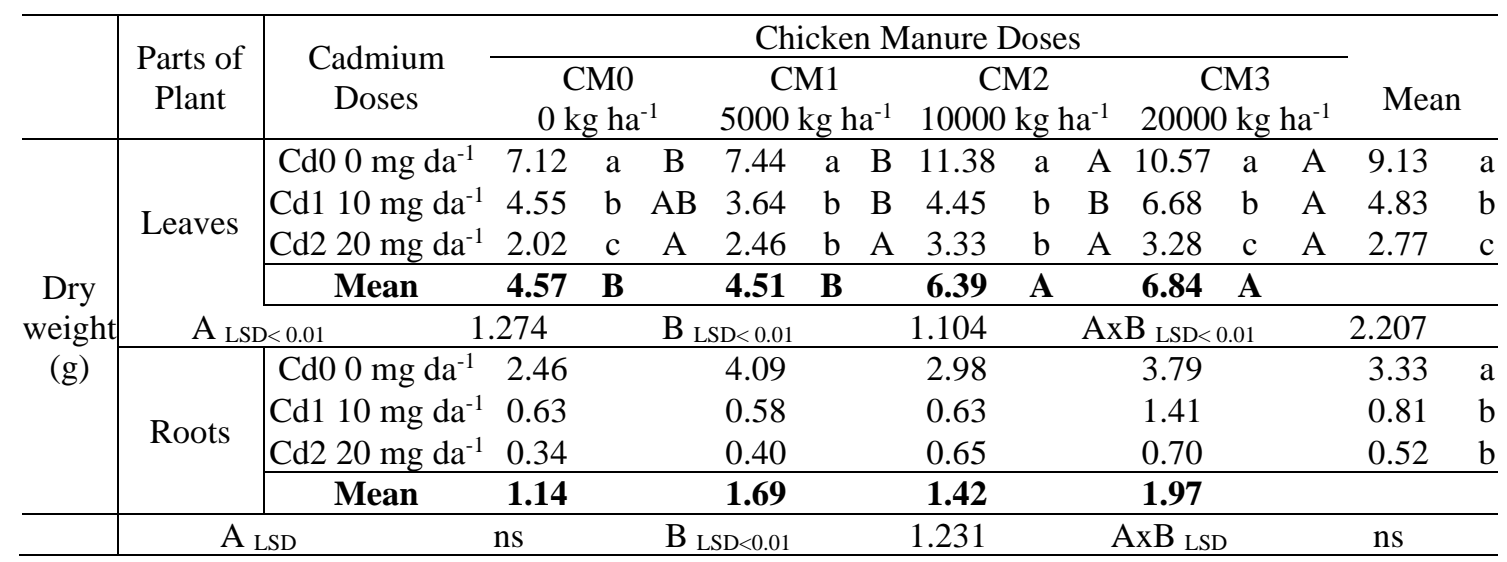

Significant differences between values in rows are symbolized by capital letters, significant differences between values in columns are symbolized by lowercase letters. ns: not significant, A: Chicken manure doses, B: Cd doses, AxB: Interaction of chicken manure and Cd doses 
Significant reductions of dry weight of spinach due to the high concentrations of $\mathrm{Cd}$ obtained from our research findings, were found similar to those in previous studies with various leafy vegetables. Chandrawal and Kumar (2016), declared significant decreases on dry weight amounts of spinach after $5 \mathrm{mg} \mathrm{kg}^{-1} \mathrm{Cd}$ application in calcareous and noncalcareous soil conditions. Chetan and Ami (2015) reported decreased growth parameters in spinach compared to the control in their study with two doses of $\mathrm{Cd}$. It has been stated that toxic Cd conditions cause reductions in growth parameters such as height, weight and leaf number of lettuce plants (Monteiro et al., 2009; Canal et al., 2018). In our previous study with the lettuce plant, we also determined degradation on dry weight amounts of the root and stem of the lettuce plant with the high doses of Cd applied to the soil (Kunene and Celik, 2020). Similarly, it has been stated that sewage water applications containing high amounts of $\mathrm{Cd}$ lead to a decrease in the biomass of leafy vegetables such as mint, coriander and fenugreek (Anwar et al., 2016), As in previous trial results, the decrease in dry matter yield observed in our experiment is thought to be due to the impaired up take of plant nutrients and their functions within the plant in the presence of high doses of Cd (Qin et al., 2020).

\section{Effects of cadmium on cadmium amounts}

Concentrations and the up-taken $\mathrm{Cd}$ amounts in the leaves and in the roots were found statistically significant $(\mathrm{p}<0.01)$. The least Cd concentrations in leaves $\left(0.58 \mathrm{mg} \mathrm{kg}^{-1}\right)$ and in roots $\left(1.23 \mathrm{mg} \mathrm{kg}^{-1}\right)$ were determined at control plants which have grown on non $\mathrm{Cd}$ applied soil conditions and increased with the applications of cadmium and were found high at the highest $\mathrm{Cd}$ doses both in the leaves (75.04 $\left.\mathrm{mg} \mathrm{kg}^{-1}\right)$ and in the roots $\left(162.17 \mathrm{mg} \mathrm{kg}^{-1}\right.$ ) (Figure 1). In our previous study with the lettuce plant, it was determined that the $\mathrm{Cd}$ doses applied to the soil increased the root and stem $\mathrm{Cd}$ concentrations (Kunene and Celik, 2020). Some studies also reported elevated plant Cd concentrations parallel with increasing $\mathrm{Cd}$ (Li et al., 2014; Bakshayesh et al., 2014). Chandrawal and Kumar (2016), reported significant increases on Cd concentrations and the up-taken amounts on both the roots and shoots of spinach with the increasing $\mathrm{Cd}$ doses in calcareous and non-calcareous soil conditions. Zhang et al. (2014), also reported increases on the Cd concentrations. Lehoczky et al. (1998), reported that there are differences between plant varieties in terms of cadmium accumulation, and in the group of edible vegetables, lettuce and spinach may accumulate the Cd element mostly.

It was also seen from the results of our research that spinach has the ability to accumulate the element cadmium in high amounts. Because of its accumulation in the roots $\left(108.10 \mathrm{mg} \mathrm{kg}^{-1}\right.$ and $\left.162.17 \mathrm{mg} \mathrm{kg}^{-1}\right)$, the amounts of $\mathrm{Cd}$ were found higher rather than in the leaves (65.71 mg kg $\mathrm{mg}^{-1}$ and $75.04 \mathrm{mg} \mathrm{kg}^{-1}$ ) (Figure 1). However, the $\mathrm{Cd}$ concentrations in the leaves were found to be substantially high when compared to non $\mathrm{Cd}$ applied control pots and also found higher than the tolerable limit for agronomic crops (0.05-0.5 mg kg-1), and toxic range (5-30 $\mathrm{mg} \mathrm{kg}^{-1}$ ) (Kabata-Pendias, 2011; Nazar et al., 2012). The World Health Organization (WHO) limited the allowable Cd amount in plants to $0.02 \mathrm{mg} \mathrm{kg}^{-1}$, it was stated that the daily Cd uptake for humans was $1 \mu \mathrm{g} \mathrm{Cd}$ per kg of the body weight, and it was calculated as $70 \mu \mathrm{g}$ for $70 \mathrm{~kg}$ body weight (Smolders, 2001; Hina et al., 2019). It has been reported that if the high concentration of $\mathrm{Cd}$ in the edible parts of plants passes into the human body, it may cause damage to the kidneys, bones, and the systems such as reproduction, nervous and cardiovascular, and can also lead to cancer (Ogundele et al., 2015; Khalid et al., 2017; Khan et al., 2017). Due to the thought that regular consumption of plants with a concentration above $3 \mathrm{mg} \mathrm{kg}^{-1} \mathrm{Cd}$ may be 
dangerous for human health, as reported by Pais and Jones (1997), consumption of plants obtained from our research conditions was found to be inconvenient.
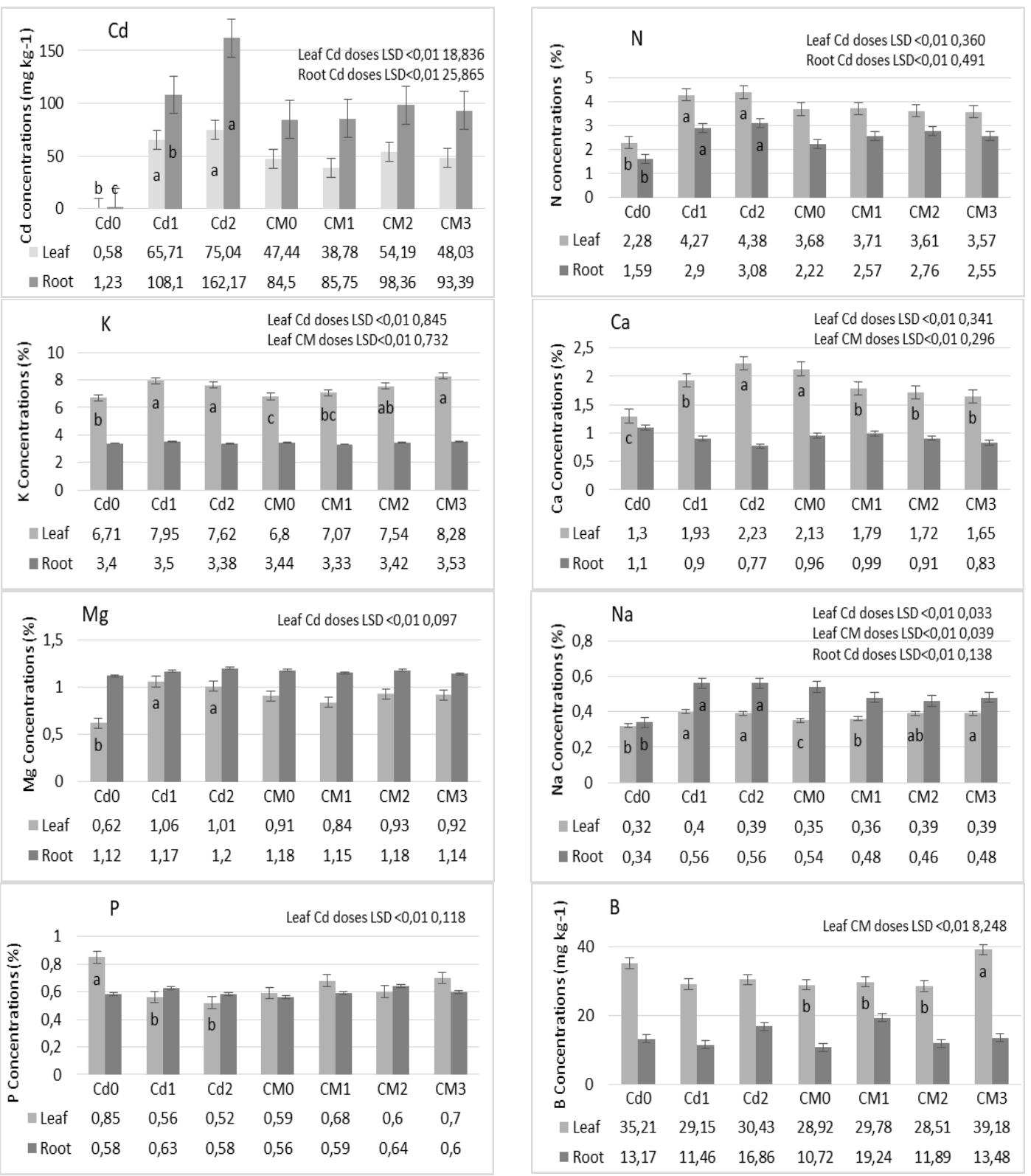

Figure 1. Effects of $C d$ and chicken manure on $C d$ and some nutrient element contents in the leaves and in the roots of spinach

As with in the concentrations, the least up-taken amount of $\mathrm{Cd}$ in the leaves $\left(5.24 \mu \mathrm{g} \mathrm{dw}^{-1}\right)$ and in the roots $\left(3.62 \mu \mathrm{g} \mathrm{dw}^{-1}\right)$ was determined at Cd0 (Table 4). Due to the $\mathrm{Cd}$ accumulation in the roots and the severe damage of the roots rather than the leaves, caused the up-taken amount of cadmium being determined more in the leaves. The highest up-taken $\mathrm{Cd}$ in the leaves $\left(314.42 \mu \mathrm{g} \mathrm{dw}^{-1}\right)$, and in the roots $\left(89.36 \mu \mathrm{g} \mathrm{dw}^{-1}\right)$ was obtained from $\mathrm{Cd} 1$. In relation to the decrease in dry weight, the amount decreased at the highest dose of $\mathrm{Cd}(\mathrm{Cd} 3)$ and obtained as $209.92 \mu \mathrm{g} \mathrm{dw}^{-1}$ in leaves and $84.74 \mu \mathrm{g} \mathrm{dw}^{-1}$ in the roots. Dotaniya et al. (2018), reported the up-taken Cd amount in leaves of spinach as 180 and 
$200 \mu \mathrm{g} \mathrm{dw}^{-1}$, respectively in their study with doses of 1 and $2 \mathrm{mg} \mathrm{kg}^{-1} \mathrm{Cd}$ doses, and was in accordance with the findings of us. However, it has been reported that the amounts taken may differ depending on $\mathrm{Cd}$ concentration, $\mathrm{pH}$, organic matter level of the soil and also species and varieties of the plant (Nazar et al., 2012; Chen et al., 2019).

Table 4. Effects of cadmium and chicken manure on $C d, N, P$, and $K$ uptake of leaf and root of spinach

\begin{tabular}{|c|c|c|c|c|c|c|c|c|c|}
\hline & \multirow{2}{*}{$\begin{array}{c}\text { Parts } \\
\text { of } \\
\text { Plant }\end{array}$} & \multirow[b]{2}{*}{$\begin{array}{l}\text { Cadmium } \\
\text { Doses }\end{array}$} & \multicolumn{5}{|c|}{ Chicken Manure Doses } & \multirow{2}{*}{\multicolumn{2}{|c|}{ Mean }} \\
\hline & & & $\begin{array}{r}\mathrm{C} \\
0 \mathrm{k} \\
\end{array}$ & $\begin{array}{l}\text { M0 } \\
\text { ha }^{-1}\end{array}$ & $\begin{array}{c}\text { CM1 } \\
5000 \mathrm{~kg} \mathrm{ha}^{-1}\end{array}$ & $\begin{array}{c}\text { CM2 } \\
10000 \mathrm{~kg} \mathrm{ha}^{-1}\end{array}$ & $\begin{array}{c}\text { CM3 } \\
20000 \mathrm{~kg} \mathrm{ha}^{-1} \\
\end{array}$ & & \\
\hline \multirow{10}{*}{$\begin{array}{c}\mathrm{Cd} \\
(\mu \mathrm{g} \\
\left.\mathrm{dw}^{-1}\right)\end{array}$} & \multirow{4}{*}{ Leaves } & $\mathrm{Cd} 00 \mathrm{mg} \mathrm{da}^{-1}$ & 3.56 & & 5.58 & 5.69 & 6.12 & 5.24 & $\mathrm{c}$ \\
\hline & & Cd1 $10 \mathrm{mg} \mathrm{da}^{-1}$ & 285.95 & & 205.09 & 355.68 & 410.96 & 314.42 & $\mathrm{a}$ \\
\hline & & $\mathrm{Cd} 220 \mathrm{mg} \mathrm{da}^{-1}$ & 168.38 & & 146.39 & 253.30 & 271.59 & 209.92 & $\mathrm{~b}$ \\
\hline & & Mean & 152.63 & 3 BC & 119.02 C & 204.89 AB & $229.55 \mathrm{~A}$ & & \\
\hline & \multirow{5}{*}{ Roots } & $\mathrm{A}_{\mathrm{LSD}}<0.05$ & & 76.436 & $\mathrm{~B}_{\mathrm{LSD}}<0.01$ & 89.649 & $\mathrm{AxB}_{\text {LSD }}$ & ns & \\
\hline & & $\mathrm{Cd} 00 \mathrm{mg} \mathrm{da}^{-1}$ & 3.11 & & 3.09 & 3.75 & 4.53 & 3.62 & b \\
\hline & & $\mathrm{Cd} 110 \mathrm{mg} \mathrm{da}^{-1}$ & 60.90 & & 64.67 & 76.84 & 155.02 & 89.36 & a \\
\hline & & $\mathrm{Cd} 220 \mathrm{mg} \mathrm{da}^{-1}$ & 50.86 & & 55.50 & 115.01 & 117.58 & 84.74 & $\mathrm{a}$ \\
\hline & & Mean & 38.29 & B & 41.09 B & $65.20 \mathrm{AB}$ & $\mathbf{9 2 . 3 8 \quad \mathrm { A }}$ & & \\
\hline & & $\mathrm{A}_{\mathrm{LSD}}<0.05$ & & 37.105 & $\mathrm{~B}_{\mathrm{LSD}}<0.01$ & 43.519 & $\mathrm{AxB}_{\mathrm{LSD}}$ & ns & \\
\hline \multirow{10}{*}{$\begin{array}{c}\mathrm{N} \\
(\mathrm{mg} \\
\left.\mathrm{dw}^{-1}\right)\end{array}$} & \multirow{4}{*}{ Leaves } & $\mathrm{Cd} 00 \mathrm{mg} \mathrm{da}^{-1}$ & 171.68 & & 173.27 & 248.61 & 227.99 & 205.39 & $\mathrm{a}$ \\
\hline & & Cd1 $10 \mathrm{mg} \mathrm{da}^{-1}$ & 192.62 & & 161.20 & 188.70 & 266.17 & 202.17 & $\mathrm{a}$ \\
\hline & & $\mathrm{Cd} 220 \mathrm{mg} \mathrm{da}^{-1}$ & 87.28 & & 106.38 & 147.05 & 146.70 & 121.86 & $\mathrm{~b}$ \\
\hline & & Mean & 150.53 & 3 B & 146.95 B & 194.79 A & 213.62 A & & \\
\hline & & $\mathrm{A}_{\mathrm{LSD}<0.01}$ & & 41.523 & $\mathrm{~B}_{\mathrm{LSD}}<0.01$ & 35.960 & $\mathrm{AxB}_{\mathrm{LSD}}$ & $\mathrm{ns}$ & \\
\hline & \multirow{4}{*}{ Roots } & $\mathrm{Cd} 00 \mathrm{mg} \mathrm{da}^{-1}$ & 41.12 & & 55.03 & 44.76 & 57.36 & 49.57 & $\mathrm{a}$ \\
\hline & & $\mathrm{Cd} 110 \mathrm{mg} \mathrm{da}^{-1}$ & 17.53 & & 16.81 & 19.64 & 37.54 & 22.88 & $b$ \\
\hline & & $\mathrm{Cd} 220 \mathrm{mg} \mathrm{da}^{-1}$ & 7.53 & & 13.77 & 21.76 & 23.46 & 16.63 & $\mathrm{~b}$ \\
\hline & & Mean & 22.06 & & 28.54 & 28.72 & 39.45 & & \\
\hline & & $\mathrm{A}_{\text {LSD }}$ & & ns & $\mathrm{B}_{\mathrm{LSD}}<0.01$ & 17.553 & $\mathrm{AxB}_{\mathrm{LSD}}$ & ns & \\
\hline \multirow{10}{*}{$\begin{array}{c}\mathrm{P} \\
(\mathrm{mg} \\
\left.\mathrm{dw}^{-1}\right)\end{array}$} & \multirow{4}{*}{ Leaves } & $\mathrm{Cd} 00 \mathrm{mg} \mathrm{da}^{-1}$ & 53.01 & a $\quad$ B & 61.40 a $B$ & 84.41 a $\mathrm{A}$ & 96.64 a & 73.87 & $\mathrm{a}$ \\
\hline & & $\mathrm{Cd} 110 \mathrm{mg} \mathrm{da}^{-1}$ & 23.79 & $\mathrm{AB}$ & $20.36 \mathrm{~b}$ & 24.85 b $A B$ & 341.15 & 27.54 & b \\
\hline & & $\mathrm{Cd} 220 \mathrm{mg} \mathrm{da}^{-1}$ & 10.33 & A & $12.05 \mathrm{~b} \quad \mathrm{~A}$ & $16.73 \quad \mathrm{~b} \quad \mathrm{~A}$ & $18.51 \mathrm{c}$ & 14.41 & $\mathrm{c}$ \\
\hline & & Mean & 29.04 & B & 31.27 B & 42.00 A & $52.10 \quad$ A & & \\
\hline & \multirow{5}{*}{ Roots } & $\mathrm{A}_{\mathrm{LSD}}<0.01$ & & 10.363 & $\mathrm{~B}_{\mathrm{LSD}}<0.01$ & 8.975 & $\mathrm{AxB}_{\text {LSD }}$ & 17.949 & \\
\hline & & $\mathrm{Cd} 00 \mathrm{mg} \mathrm{da}^{-1}$ & 14.14 & & 21.73 & 17.70 & 19.75 & 18.33 & $\mathrm{a}$ \\
\hline & & $\mathrm{Cd} 110 \mathrm{mg} \mathrm{da}^{-1}$ & 3.49 & & 3.45 & 4.15 & 8.92 & 5.00 & b \\
\hline & & $\mathrm{Cd} 220 \mathrm{mg} \mathrm{da}^{-1}$ & 1.77 & & 2.25 & 3.88 & 3.99 & 2.97 & $\mathrm{~b}$ \\
\hline & & Mean & 6.46 & & 9.14 & 8.58 & 10.89 & & \\
\hline & & $\mathrm{A}_{\text {LSD }}$ & & ns & $\mathrm{B}_{\mathrm{LSD}}<0.01$ & 5.935 & $\mathrm{AxB}_{\mathrm{LSD}}$ & ns & \\
\hline \multirow{10}{*}{$\begin{array}{c}\mathrm{K} \\
(\mathrm{mg} \\
\left.\mathrm{dw}^{-1}\right)\end{array}$} & \multirow{4}{*}{ Leaves } & $\mathrm{Cd} 00 \mathrm{mg} \mathrm{da}^{-1}$ & 448.49 & $\begin{array}{ll}\mathrm{a} & \mathrm{B}\end{array}$ & $477.41 \mathrm{a} \quad \mathrm{B}$ & $766.07 \quad \mathrm{a}$ & $768.43 \mathrm{a}$ & 615.10 & $\mathrm{a}$ \\
\hline & & Cd1 $10 \mathrm{mg} \mathrm{da}^{-1}$ & 320.61 & B & $275.80 \mathrm{~b} \quad \mathrm{~B}$ & $366.37 \mathrm{~b} \quad \mathrm{~B}$ & $582.88 \mathrm{~b}$ & 386.42 & b \\
\hline & & $\mathrm{Cd} 220 \mathrm{mg} \mathrm{da}^{-1}$ & 142.44 & $\mathrm{~B}$ & $177.73 \mathrm{~b} \quad \mathrm{AB}$ & $252.09 \mathrm{~b} \quad \mathrm{AB}$ & $3285.79 \mathrm{c}$ & 214.51 & $\mathrm{c}$ \\
\hline & & Mean & 303.84 & $\mathbf{C}$ & 310.31 C & 461.51 B & 545.70 A & & \\
\hline & & $\mathrm{A}_{\mathrm{LSD}}<0.01$ & & 80.878 & $\mathrm{~B}_{\mathrm{LSD}<0.01}$ & $70.042 \mathrm{Ax}$ & $\mathrm{xB}$ LSD $<0.01$ & 140.084 & \\
\hline & \multirow{4}{*}{ Roots } & $\mathrm{Cd} 00 \mathrm{mg} \mathrm{da}{ }^{-1}$ & 98.17 & & 124.64 & 84.73 & 101.51 & 102.26 & $\mathrm{a}$ \\
\hline & & $\mathrm{Cd} 110 \mathrm{mg} \mathrm{da}^{-1}$ & 22.31 & & 19.24 & 19.10 & 55.80 & 29.12 & b \\
\hline & & $\mathrm{Cd} 220 \mathrm{mg} \mathrm{da}^{-1}$ & 9.61 & & 13.07 & 23.66 & 25.62 & 17.99 & $\mathrm{~b}$ \\
\hline & & Mean & 43.37 & & 52.32 & 42.50 & 60.98 & & \\
\hline & & $\mathrm{A}_{\mathrm{LSD}}$ & & $\mathrm{ns}$ & $\mathrm{B}_{\mathrm{LSD}}<0.01$ & 29.778 & $\mathrm{AxB}$ LSD & ns & \\
\hline
\end{tabular}

Significant differences between values in rows are symbolized by capital letters, significant differences between values in columns are symbolized by lowercase letters. ns: not significant, A: Chicken manure doses, B: Cd doses, AxB: Interaction of chicken manure and $\mathrm{Cd}$ doses 


\section{Effects of cadmium on some nutrient element amounts}

Soil applied cadmium doses affected the concentrations of the nutrient elements except $B$ in the leaves also significantly $(p<0.01)$, however the effects in the roots of the spinach plant, were not found significant except $\mathrm{N}$ and $\mathrm{Na}$. Along with the increased cadmium doses, concentrations of $\mathrm{N}, \mathrm{K}, \mathrm{Ca}$ and $\mathrm{B}$ in the leaves were found higher than in the roots (Figure 1). N, K, Mg and Na concentrations in the leaves and in the roots increased due to the decreased dry weight amounts of spinach. While the lowest concentrations in the roots $(1.59 \% \mathrm{~N}, 3.4 \% \mathrm{~K}, 1.12 \% \mathrm{Mg}$ and $0.34 \% \mathrm{Na})$ and in the leaves $(2.28 \% \mathrm{~N}, 6.71 \%$ $\mathrm{K}, 0.62 \% \mathrm{Mg}$ and $\% 0.32 \mathrm{Na})$ were determined at $\mathrm{Cd} 0$. Statistically significant $(\mathrm{p}<0.01)$ elevations occurred at the concentrations of $\mathrm{N}, \mathrm{K}, \mathrm{Ca}, \mathrm{Mg}$ and $\mathrm{Na}$ with increasing the doses of cadmium. The highest concentrations of nitrogen in the roots $(3.08 \% \mathrm{~N})$ and in the leaves $(4.38 \% \mathrm{~N}$,) were determined at $\mathrm{Cd} 2$. However, the highest potassium concentration in the roots $(3.5 \% \mathrm{~K})$ and in the leaves $(7.95 \% \mathrm{~K})$ were determined at $\mathrm{Cd} 1$. The highest $\mathrm{Mg}$ and $\mathrm{Na}$ concentrations in the leaves $(1.06 \% \mathrm{Mg}, 0.4 \% \mathrm{Na}$ ) were determined at $\mathrm{Cd} 1$ and in the roots $(1.2 \% \mathrm{Mg}, 0.56 \% \mathrm{Na})$ were determined at $\mathrm{Cd} 2$ (Figure 1).

Similar to $\mathrm{N}$ and $\mathrm{K}$, concentrations of $\mathrm{Ca}$ in the leaves were found higher than in the roots. Increasing the soil applied cadmium doses, significantly $(\mathrm{p}<0.01)$ affected the concentrations of $\mathrm{Ca}$ in the leaves, but not in the roots. The least $\mathrm{Ca}$ concentration in the leaves $(1.3 \% \mathrm{Ca})$ was obtained at $\mathrm{Cd} 0$ and elevated with increasing doses. However, the highest concentration $(1.1 \%)$ in the roots were determined at $\mathrm{Cd} 0$ and fall down due to the sharp decrease of root dry weight amounts of spinach (Figure 1).

Concentrations of $\mathrm{P}(0.85 \% \mathrm{P})$ and $\mathrm{B}\left(35.21 \mathrm{mg} \mathrm{kg}^{-1} \mathrm{~B}\right)$ in the leaves of control plants were found high, and decreased with the application of $\mathrm{Cd}\left(0.52 \% \mathrm{P}, 29.15 \mathrm{mg} \mathrm{kg}^{-1} \mathrm{~B}\right)$. These decreases, were found significant $(\mathrm{p}<0.01)$ at only the concentrations of $\mathrm{P}$ in the leaves but not at the concentrations of B in the leaves. However, due to the decrease in dry weight, the concentrations of $\mathrm{P}$ and $\mathrm{B}$ in the roots increased but not found statistically significant. The highest $\mathrm{P}(0.63 \% \mathrm{P})$ was determined at the first $\mathrm{Cd}$ dose and the highest $\mathrm{B}\left(16.86 \mathrm{mg} \mathrm{kg}^{-1} \mathrm{~B}\right)$ was determined at the second $\mathrm{Cd}$ doses. In contrast to $\mathrm{B}$, concentration of $\mathrm{P}$ in the roots was found higher than in the leaves (Figure 1).

Although $\mathrm{Cd}$ is not an essential nutrient for plants it has been observed that it is easily up-taken from the soil, accumulates in plant tissues by damaging the roots, inhibits the intake of plant nutrients, decreased the dry matter yield with unbalanced plant nutrition. This was also found compatible with the previous results from other research experiments (Barut, 2019). Based on previous studies, either synergistic or antagonistic relations among Cd ions and essential macro and micro plant nutrients were reported (Jibril et al., 2017; Barut, 2019). Zhang et al. (2014) reported increases on the Cd concentrations and also increase on $\mathrm{Mg}$ and $\mathrm{Ca}$ in the roots. Gussarsson (1994), reported that the $\mathrm{Ca}, \mathrm{Mg}, \mathrm{K}$, and Mn levels of Birch seedlings decreased with the applications of $\mathrm{Cd}$. Chen et al. (2019), reported alleviating effects of $\mathrm{B}$ on $\mathrm{Cd}$ accumulation and toxicity in rice plants by improving oxidative stress and suppressing Cd uptake.

Soil applied Cd significantly affected the up-taken amounts of the nutrient elements $(\mathrm{N}, \mathrm{P}, \mathrm{K}, \mathrm{Ca}, \mathrm{Mg}, \mathrm{Na}, \mathrm{B})(\mathrm{p}<0.01)$ (Tables 4 and 5). Due to the decrease in dry weight with increasing cadmium doses, the up-taken amounts of the nutrients were found to be higher in the leaves compared to the roots. The highest up-taken amounts of the nutrient elements in the leaves $\left(205.39 \mathrm{mg} \mathrm{N} \mathrm{dw}\right.$, $73.87 \mathrm{mg} \mathrm{P} \mathrm{dw}^{-1}, 615.10 \mathrm{mg} \mathrm{K} \mathrm{dw}^{-1}$, $117.45 \mathrm{mg} \mathrm{Ca} \mathrm{dw}^{-1}, 56.60 \mathrm{mg} \mathrm{Mg} \mathrm{dw}{ }^{-1}, 29.15 \mathrm{mg} \mathrm{Na} \mathrm{dw}^{-1}$, and $302.86 \mu \mathrm{g} \mathrm{B} \mathrm{dw}^{-1}$ ) and in the roots $\left(49.57 \mathrm{mg} \mathrm{N} \mathrm{dw}^{-1}, 18.33 \mathrm{mg} \mathrm{P} \mathrm{dw}^{-1}, 102.26 \mathrm{mg} \mathrm{K} \mathrm{dw}^{-1}, 41.69 \mathrm{mg} \mathrm{Ca} \mathrm{dw}^{-1}\right.$, 
$37.51 \mathrm{mg} \mathrm{Mg} \mathrm{dw}{ }^{-1}, 10.49 \mathrm{mg} \mathrm{Na} \mathrm{dw}^{-1}$, and $43.08 \mu \mathrm{g} \mathrm{B} \mathrm{dw}^{-1}$ ) were determined at $\mathrm{Cd} 0 . \mathrm{In}$ contrast, the least up-taken amounts of the nutrient elements in the leaves $(121.86 \mathrm{mg}$ $\mathrm{N} \mathrm{dw}^{-1}, 14.41 \mathrm{mg} \mathrm{P} \mathrm{dw}{ }^{-1}, 214.51 \mathrm{mg} \mathrm{K} \mathrm{dw}^{-1}, 60.13 \mathrm{mg} \mathrm{Ca} \mathrm{dw}{ }^{-1}, 28.22 \mathrm{mg} \mathrm{Mg} \mathrm{dw}^{-1}$, $10.90 \mathrm{mg} \mathrm{Na} \mathrm{dw}^{-1}$, and $\left.84.02 \mu \mathrm{g} \mathrm{B} \mathrm{dw}^{-1}\right)$ and in the roots $\left(16.63 \mathrm{mg} \mathrm{N} \mathrm{dw}^{-1}, 2.97 \mathrm{mg}\right.$ $\mathrm{P} \mathrm{dw}^{-1}, 17.99 \mathrm{mg} \mathrm{K} \mathrm{dw} w^{-1}, 3.97 \mathrm{mg} \mathrm{Ca} \mathrm{dw}{ }^{-1}, 6.31 \mathrm{mg} \mathrm{Mg} \mathrm{dw}^{-1}, 2.91 \mathrm{mg} \mathrm{Na} \mathrm{dw}^{-1}$, and $8.99 \mu \mathrm{g} \mathrm{B} \mathrm{dw}^{-1}$ ) were determined at $\mathrm{Cd} 2$ (Tables 4 and 5). Similar to the negative effect of $\mathrm{Cd}$ on the nutrient elements up-take in our research, its competition with $\mathrm{K}, \mathrm{Ca}, \mathrm{Mg}$ was also reported in some other researches (Benavides et al., 2005). Li et al. (2012), in the study of rice seedlings, they stated that calcium $(\mathrm{Ca})$ and potassium $(\mathrm{K})$ uptake was impaired in both roots and shoots with $\mathrm{Cd}$ applications. Contamination degree of the soil, the plant species, plant parts, rhizosphere are important factors on nutrient uptake. However, not only $\mathrm{Cd}$ but also concentrations of the other nutrient elements, their interactions with each other for precipitation, absorption ability from the roots and bindings with organic compounds within the medium are also quite important factors effecting their competition.

\section{Effects of chicken manure on dry weight amounts}

Application of chicken manure had statistically significant effect on the dry weight yield of spinach leaves and its interaction with $\mathrm{Cd}$ also found effective $(\mathrm{p}<0.01)$. However, the effect on the dry weight of roots was found not significant. The highest dry weight in leaves $(6.84 \mathrm{~g})$ was found at CM3 (Table 3). The highest leaf dry weight $(11.38 \mathrm{~g})$ was obtained from $\mathrm{Cd} 0 \mathrm{xCM} 2$ interaction. In contrast, the least dry weight in leaves $(2.02 \mathrm{~g})$ was determined at $\mathrm{Cd} 2 \mathrm{xCM} 0$ interaction.

The use of chicken manure is widespread, as it is rich in nutrients and is also a soil improvement material that improves the physical, chemical and biological properties of the soil (Ravindran et al., 2017). It has been stated that the hormone like behaviour of humic substance in chicken manure, increases the uptake of plant nutrients, stimulates plant growth and has a positive effect on increasing dry matter amounts, when applied in small quantities (Dikinya and Mufwanzala, 2010; Adesoye et al., 2014; Hina et al., 2019). In this respect, it can be an important alternative in terms of regulating toxicity problems in some areas, but ineffective and even quite negative effects on development have also been reported when applied in large amounts (Leventoğlu and Erdal, 2014).

\section{Effects of chicken manure on Cd amounts}

Soil applied chicken manure significantly affected $(\mathrm{p}<0.05)$ the up-taken $\mathrm{Cd}$ amounts of the spinach plant, however the effects on the $\mathrm{Cd}$ concentrations were not found significant (Figure 1 and Table 4). Although the first dose of chicken manure (CM1) decreased the concentrations and the up-taken amounts of $\mathrm{Cd}$ compared to control, $\mathrm{Cd}$ concentration and the up-taken amount by the plant, has increased with the increasing doses of chicken manure. The highest up-taken Cd in the leaves $\left(229.55 \mu \mathrm{g} \mathrm{dw}^{-1}\right)$ and in the roots $\left(92.38 \mu \mathrm{g} \mathrm{dw}^{-1}\right)$ was determined at CM3 (Table 4). Precipitation, absorbtion or complexation capabilities of nutrient elements and metals with organic matter, may change depending on the $\mathrm{pH}$ of the rhizosphere, redox potential and chelating capacity. Immobilization of heavy metals in soil with manure applications were reported depending on physical and chemical characteristic of the amendment materials and also the soil type (Kamari et al., 2014). 
Table 5. Effects of cadmium and chicken manure on $\mathrm{Ca}, \mathrm{Mg}, \mathrm{Na}$, and $\mathrm{B}$ uptake of leaf and root of spinach

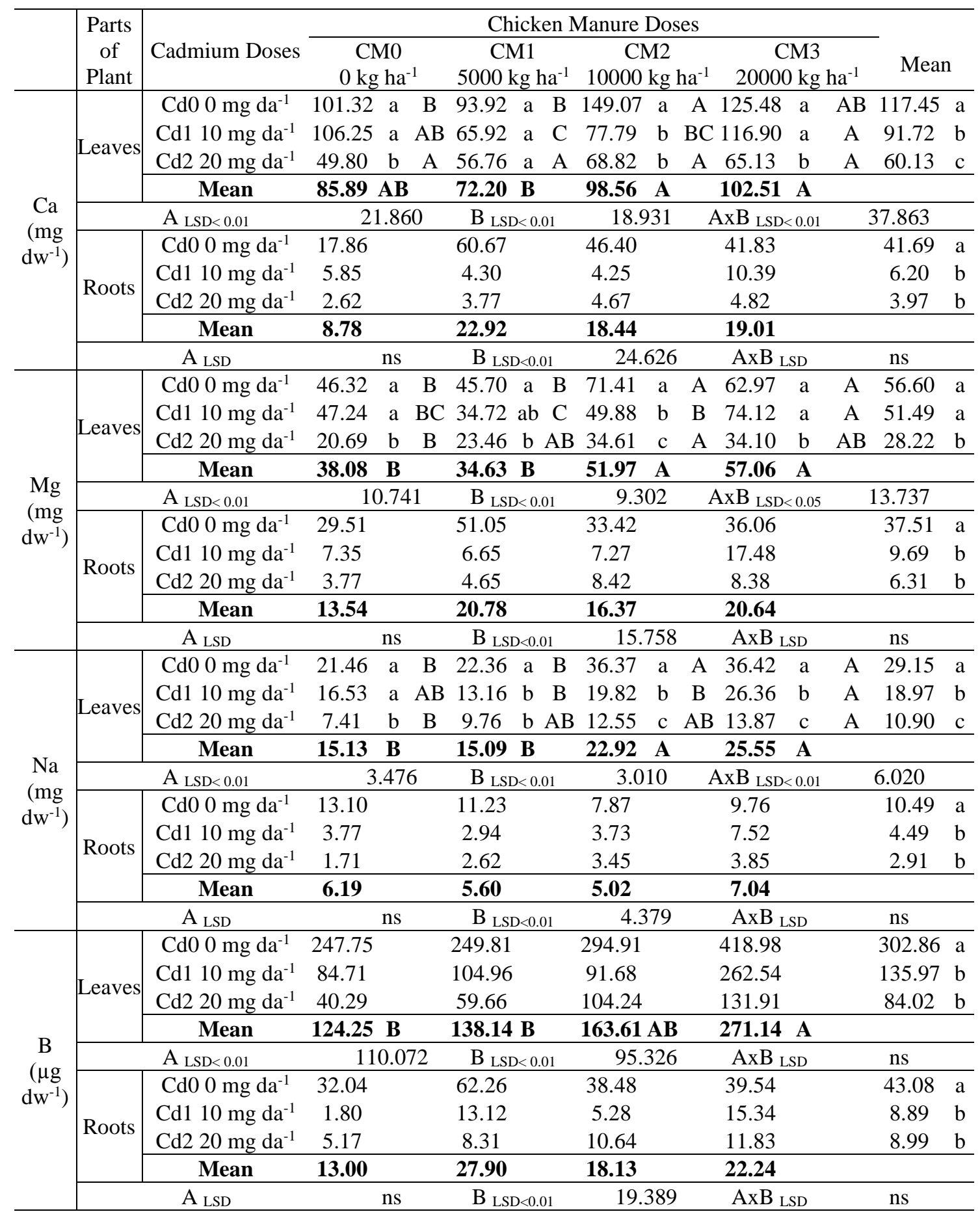

Significant differences between values in rows are symbolized by capital letters, significant differences between values in columns are symbolized by lowercase letters. ns: not significant, A: Chicken manure doses, B: Cd doses, AxB: Interaction of chicken manure and Cd doses

If they bound in to chelate complex, the solubility and availability of the Cd could be reduced and because of their interaction, decreased heavy metal uptake by plants with organic amendments were also reported (Nazar et al., 2012; Canal et al., 2018). On the 
other hand, it was also reported that organa-metal compounds may increase the solubility and availability of heavy metals in plants (Leventoğlu and Erdal, 2014). Parallel to the findings of us, Chandrawal and Kumar (2016), reported significant increases on Cd concentrations and the up-taken amounts on both the roots and shoots of spinach with the increasing farmyard manure application in calcareous and non-calcareous soil conditions. The amounts were determined much more in non-calcareous conditions. Stimulating effects of humic matter on plant growth are associated with increased uptake of the nutrient elements. In addition to the nutrient elements, poultry manure can also contain many heavy metals depending on the production and management process of the poultry manure and may increase $\mathrm{As}, \mathrm{Cd}, \mathrm{Cu}$ and $\mathrm{Mn}$ amounts of the soils (Ukpe and Chokor, 2018) or some soil applied organic materials also reduce the mobility and uptake of heavy metals in the soil by increasing the surface charges and supply the retention of $\mathrm{Cd}$ in the soil (Hina et al., 2019). It was reported that the absorbtion ability of soil depends on its ability to form $\mathrm{pH}$-dependent surface load of organic matter, cation exchange capacity, clay minerals and hydrated iron and manganese oxides (Pierzynski et al., 2005; Bolan et al., 2014; Zhou et al., 2018). Therefore, organic amendments involving humic substances increase the uptake of these elements increasing the surface charge and form complexes with metal cations and organic bond fractions, or conversely, they compete with roots and reduce their uptake (Hina et al., 2019; Khan et al., 2017).

\section{Effects of chicken manure on some nutrient element amounts}

Soil applied chicken manure significantly affected the concentrations of $\mathrm{K}, \mathrm{Ca}, \mathrm{Na}$ and $B$ of the leaves $(\mathrm{p}<0.01)$. However, the nutrient element concentrations were not found significant in the roots (Figure 1). Concentrations of $\mathrm{K}, \mathrm{Na}$ and $\mathrm{B}$ in the leaves increased and the highest amounts $\left(8.28 \% \mathrm{~K}, 0.39 \% \mathrm{Na}, 39.18 \mathrm{mg} \mathrm{kg}^{-1} \mathrm{~B}\right)$ were found at the highest dose of chicken manure (CM3) (Figure 1). In contrast, the concentrations of Ca decreased with the addition of chicken manure. While the highest concentration of $\mathrm{Ca}$ was found at control $(2.13 \% \mathrm{Ca})$, the least amount $(1.65 \% \mathrm{Ca})$ was determined at CM3 (Figure 1).

Chicken manure significantly affected the up-taken $\mathrm{N}, \mathrm{P}, \mathrm{K}, \mathrm{Ca}, \mathrm{Mg}, \mathrm{Na}$ and $\mathrm{B}$ amounts of the leaves $(p<0.01)$, however, the effects in the roots were found not significant. The highest up-taken amounts of $\mathrm{N}, \mathrm{P}, \mathrm{K}, \mathrm{Ca}, \mathrm{Mg}, \mathrm{Na}$ and $\mathrm{B}$ were determined at the highest dose of chicken manure (CM3) and were found as $213.62 \mathrm{mg} \mathrm{N} \mathrm{dw}^{-1}$, $52.10 \mathrm{mg} \mathrm{P} \mathrm{dw}^{-1}, 545.70 \mathrm{mg} \mathrm{K} \mathrm{dw}^{-1}, 102.51 \mathrm{mg} \mathrm{Ca} \mathrm{dw}^{-1}, 57.06 \mathrm{mg} \mathrm{Mg} \mathrm{dw}^{-1}, 25.55 \mathrm{mg}$ $\mathrm{Na} \mathrm{dw}^{-1}$ and $271.14 \mu \mathrm{g} \mathrm{B} \mathrm{dw}{ }^{-1}$, respectively (Tables 4 and 5).

Interactions between chicken manure and $\mathrm{Cd}$ were also found statistically significant $(\mathrm{p}<0.01)$ on the up-taken $\mathrm{P}, \mathrm{K}, \mathrm{Ca}, \mathrm{Mg}$, and $\mathrm{Na}$ amounts of the leaves of the spinach plant. The highest $\mathrm{P}, \mathrm{K}$, and $\mathrm{Na}$ uptake (96.64 $\mathrm{mg} \mathrm{P} \mathrm{dw}^{-1}, 768.43 \mathrm{mg} \mathrm{K} \mathrm{dw}^{-1}, 36.42 \mathrm{mg} \mathrm{Na} \mathrm{dw}^{-1}$ ) was obtained from spinach plants at $\mathrm{Cd} 0 \mathrm{xCM} 3$ interaction. However, the highest $\mathrm{Ca}$ and Mg uptake (149.07 mg Ca dw $\mathrm{mg}^{-1}, 71.41 \mathrm{mg} \mathrm{Mg} \mathrm{dw}^{-1}$ ) was obtained from Cd0xCM2 interaction. In contrast, the least $\mathrm{P}, \mathrm{K}, \mathrm{Na}, \mathrm{Ca}$ and $\mathrm{Mg}$ uptake (10.33 $\mathrm{mg} \mathrm{P} \mathrm{dw}^{-1}, 142.44 \mathrm{mg}^{-1}$ $\mathrm{K} \mathrm{dw}^{-1}, 7.41 \mathrm{mg} \mathrm{Na} \mathrm{dw}^{-1}, 49.80 \mathrm{mg} \mathrm{Ca} \mathrm{dw}^{-1}$, and $20.69 \mathrm{mg} \mathrm{Mg} \mathrm{dw}^{-1}$ ) was obtained from $\mathrm{Cd} 2 \mathrm{xCM} 0$ interaction (Tables 4 and 5).

It has been observed from our research findings that the chicken manure we applied has a positive effect on the nutrient uptake of the plants. Although antagonism of cadmium with the elements $\mathrm{K}, \mathrm{Ca}, \mathrm{Mg}, \mathrm{Fe}, \mathrm{Mn}, \mathrm{Cu}, \mathrm{Zn}$ and $\mathrm{Ni}$ were reported in past researches (Yang et al., 1998; Benavides et al., 2005), despite the Cd doses, effect of chicken manure on nutrient uptake was found to be positive. Chicken manure with its humic substances and nutrient element constituents is defined as an organic fertilizer that 
stimulates plant growth and increases the amount of dry matter by exhibiting behaviors similar to growth hormones in plants, as well as a soil improvement material that improves the physical, chemical, and also the biological properties of the soil (Dikinya and Mufwanzala, 2010; Adesoye et al., 2014; Ravindran et al., 2017; Hina et al., 2019). Contamination degree of the soil, the plant species, plant parts, rhizosphere are important factors on nutrient uptake. However, not only $\mathrm{Cd}$ but also the nutrient elements concentrations, their interactions with each other for precipitation, absorption ability from the roots and bindings with organic compounds within the medium are quite important. This was also found compatible with the previous results from other research experiments (Dikinya and Mufwanzala, 2010; Kabata-Pendias, 2011; Nazar et al., 2012; Adesoye et al., 2014; Ravindran et al., 2017; Kumarpandit et al., 2017; Chen et al., 2019; Hina et al., 2019).

\section{Conclusion}

High cadmium amounts in the soil, increased the concentrations and the up-taken $\mathrm{Cd}$ both in the roots and in the leaves of spinach. Accumulation of Cd especially in the roots, caused degradation on the dry weights. Although the concentrations of $\mathrm{Cd}$ were found higher in the roots rather than leaves, they all found over the limits of WHO. Because of the severe degradation in the roots, the up-taken amounts of $\mathrm{Cd}$ were found high in the leaves. Increased $\mathrm{Cd}$, also decreased the up-taken amounts of other nutrient elements. However, the concentrations of some of the nutrient elements $(\mathrm{N}, \mathrm{K}, \mathrm{Ca}, \mathrm{Mg}, \mathrm{Na}$, and $\mathrm{Mg}$ ) were found higher than control. It should be kept in mind that this situation may cause a false perception that the plants are fed by nutrients within their sufficiency limits. Under toxic conditions of $\mathrm{Cd}$, application of chicken manure to the soil improved the dry weight of the plants, and elevated the up-taken amounts of the nutrient elements but not found proficient to decrease the amount of $\mathrm{Cd}$ below the WHO limits. Because of its tolerance to toxicity, not showing chlorotic or necrotic toxicity symptoms, will not prevent human consumption however its high $\mathrm{Cd}$ constituents will cause cadmium accumulation in people unconsciously. For this reason, it has been concluded that it is very important for human health to closely monitor the areas where the plants are grown and the heavy metal amounts of the plants that are widely consumed by humans and capable of accumulating heavy metals. In the future studies, various field researches should be carried out to investigate the hyperacumulatory properties of vegetables such as spinach, which are directly consumed by humans, and the heavy metal concentration levels in the soils where these vegetables are grown.

Acknowledgements. This article has been prepared using the data contained in the MSc. thesis.

\section{REFERENCES}

[1] Adesoye, A. M., Adekola, F. A., Olukomaiya, K. O., Olukomaiya, O. O., Iwuchukwu, P. O. (2014): Evaluation of physical properties and heavy metal composition of manure of some domestic animals. - International Journal of Innovation and Scientific Research 9(2): 293-296.

[2] Adhikari, T., Singh, M. V. (2008): Remediation of Cadmium Pollution in Soils by Different Amendments: A Column Study. - Soil Science and Plant Analysis 39: 386-96. 
[3] Ali, H., Khan, E. (2018): What Are Heavy Metals? Longstanding Controversy Over The Scientific Use of The Term 'Heavy Metals' - Proposal of A Comprehensive Definition. Toxicological and Environmental Chemistry 100(1): 6-19.

[4] Antoniadis, V., Shaheen, S. M., Levizou, E., Shahid, M., Niazi, N. K., Vithanage, M., Ok, Y. S., Bolan, N., Rinklebe, J. (2019): A Critical Prospective Analysis of the Potential Toxicity of Trace Element Regulation Limits in Soils Worldwide: Are They Protective Concerning Health Risk Assessment? - A Review. - Environment International 127: 819847.

[5] Anwar, S., Nawaz, M. F., Gul, S., Rizwan, M., Ali, S., Kareem, A. (2016): Uptake and Distribution of Minerals and Heavy Metals in Commonly Grown Leafy Vegetable Species Irrigated with Sewage Water. - Environmental Monitoring and Assessment 188(9): 541.

[6] Bakhshayesh, B. E., Delkash, M., Scholz, M. (2014): Response of Vegetables to Cadmium Enriched-Soil. - Water 6(5): 1246-1256.

[7] Barut, H. (2019): Cadmium-Induced Changes In Growth and Micronutrient Composition of Two Pepper Cultivars. - Applied Ecology and Environmental Research 17(2): 22492256.

[8] Benavides, M. P., Gallego, M. S., Tomaro, L. M. (2005): Cadmium Toxicity in Plants. Brazilian Journal of Plant Physiology 17(1): 21-34.

[9] Bolan, N., Kunhikrishnan, A., Thangarajan, R., Kumpiene, J., Park, J., Makino, T., Kirkham, M. B., Scheckel, K. (2014): Remediation of Heavy Metal (Loid) S Contaminated Soils - To Mobilize or to Immobilize? - Journal of Hazardous Materials 266: 141-166.

[10] Canal, S. B., Bozkurt, M. A., Kipcak, S. (2018): The Effects of Organic Amendments on Cadmium Uptake of Spinach (Spinacia Oleracea L.) and Plant Growth Under Cadmium Toxicity. - Fresenius Environmental Bulletin 27(5): 3174-3179.

[11] Celik, H., Turan, M. A., Așik, B. B., Katkat, A. V. (2017): Evaluation of Analytical Methods for Boron Determination in Maize Shoots. - Communications in Soil Science and Plant Analysis 48(21): 2573-2581.

[12] Chandrawal, A. K., Kumar, A. (2016): Effect of Cadmium Application Alone or Along with Fym on Spinach Grown on Calcareous and Non-Calcareous Soil. - International Journal of Bio-Resource and Stress Management 7(4): 725-731.

[13] Chen, D., Chen, D., Xue, R., Long, J., Lin, X., Lin, Y., Song, Y. (2019): Effects of Boron, Silicon and Their Interactions a Cadmium Accumulation and Toxicity in Rice Plants. Journal of Hazardous Materials 367: 447-455.

[14] Chetan, A., Ami, P. (2015): Effects of Heavy Metals ( $\mathrm{Cu}$ and $\mathrm{Cd}$ ) on Growth of Leafy Vegetables - Spinacia Oleracea and Amaranthus Caudatus. - International Research Journal of Environment Sciences 4(6): 63-69.

[15] Dikinya, O., Mufwanzala, N. (2010): Chicken Manure Enhanced Soil Fertility and Productivity: Effects of Application Rates. - Journal of Soil Science and Environmental Management 1(3): 46-54.

[16] Dorak, S., Çelik, H. (2020): Seasonal Variation of Some Trace Element and Heavy Metal Concentrations in A Turkish Stream. - Polish Journal of Environmental Studies 29(1): 589600 .

[17] Dotaniya, M. L., Rajendiran, S., Coumar, M. V., Meena, V. D., Saha, J. K., Kundu, S., Kumar, A., Patra, A. K. (2018): Interactive Effect of Cadmium and Zinc on Chromium Uptake in Spinach Grown in Vertisol of Central India. - International Journal of Environmental Science and Technology 15(2): 441-448.

[18] Gussarsson, M. (1994): Cadmium-Induced Alterations in Nutrient Composition and Growth of Betula Pendula Seedlings: The Significance of Fine Roots as A Primary Target for Cadmium Toxicity. - Journal of Plant Nutrition 17: 2151-2163.

[19] Hansen, T. H., de Bang, T. C., Laursen, K. H., Pedas, P., Husted, S., Schjorring, J. K. (2013): Multi Element Plant Tissue Analysis Using ICP Spectrometry. - In: Maathuis, F. J. (ed.) Plant Mineral Nutrients. Methods in Molecular Biology (Methods and Protocols). Humana Press, Totowa, Nj. 953. pp. 121-141. 
[20] Hina, K., Kanwal, S. S., Arshad, M., Gul, I. (2019): Effect of Cadmium (Cd) Stress on Spinach (Spinacea Oleracea) and Its Retention Kinetics in Soil in Response to Organic Amendments. - Pakistan Journal of Agricultural Sciences 56(1): 179-185.

[21] Horneck, D. A., Hanson, D. (1998): Determination of Potassium and Sodium by Flame Emission Spectrophotometry. - In: Karla, Y. P. (ed.) Handbook of Reference Methods for Plant Analysis. Washington, D.C. Crc Press. pp. 158-160.

[22] Jibril, S. A., Hassan, S. A., Ishak, C. F., Megat Wahab, P. E. (2017): Cadmium Toxicity Affects Phytochemicals and Nutrient Elements Composition of Lettuce (Lactuca Sativa L.). - Advances in Agriculture. https://doi.org/10.1155/2017/1236830.

[23] Kabata-Pendias, A. (2011): Trace Elements in Soils and Plants. $-4^{\text {th }}$ ed.; Crc Press, Boca Raton, FL., USA, 548p.

[24] Kacar, B. (2014): Plant, Soil and Fertilizer Analysis 2. - Nobel Publishers, Ankara, 423 p.

[25] Kamari, A., Mohd Yusof, S. N., Putra, W. P., Ishak, C. F., Hashim, N., Mohamed, A., Phillip, E. (2014): Metal Uptake in Water Spinach Grown on Contaminated Soil Amended with Chicken Manure and Coconut Tree Sawdust. - Environmental Engineering and Management Journal (Eemj) 13(9): 2219-2228.

[26] Khalid, S., Shahid, M., Nizai, N. K., Murtaza, B., Bibi, I., Dumat, C. (2017): A Comparison of Technologies for Remediation of Heavy Metal Contaminated Soils. - J. Geochem. Explor. 182: 247-268.

[27] Khan, M. A., Khan, S., Khan, A., Alam, M. (2017): Soil Contamination with Cadmium, Consequences and Remediation Using Organic Amendments. - Sci. Total Environ 601: 1591-1605.

[28] Kumarpandit, T., Kumarnaik, S., Patra, P. K., Dey, N., Patra, P. K., Das, D. K. (2017): Influence of Organic Manure and Lime on Cadmium Mobility in Soil and Uptake by Spinach (Spinacia Oleracea L.). - Communications in Soil Science and Plant Analysis 48(4): 357-369.

[29] Kunene, S. S., Celik, H. (2020): The Effect of Cadmium on The Growth of Lettuce Plant and on Some Element Amounts. - International African Conference on Current Studies of Science, Technology and Social Sciences, 6-7 July 2020, Johannesburg, South Africa. Conference Proceedings Book, pp. 47-58.

[30] Lehoczky, E., Szabo, L., Horvath, Sz. (1998): Cadmium Uptake by Lettuce in Different Soils. - Commun. Soil Sci. Plant Anal. 29(11-4): 1903-1912.

[31] Leventoglu, H., Erdal, İ. (2014): Effect of High Humic Substance Levels on Growth and Nutrient Concentration of Corn Under Calcareous Conditions. - Journal of Plant Nutrition 37(12): 2074-2084.

[32] Li, S., Yu, J., Zhu, M., Zhao, F., Luan, S. (2012): Cadmium Impairs Ion Homeostasis by Altering $\mathrm{K}^{+}$and $\mathrm{Ca}^{2+}$ Channel Activities in Rice Root Hair Cells. - Plant Cell Environ. 35(11): 1998-2013.

[33] Li, S., Wang, F., Ru, M., Ni, W. (2014): Cadmium Tolerance and Accumulation of Elsholtzia Argyi Oriigining from a Zinc/Lead Mining Site - A Hydroponics Experiment. International Journal of Phytoremediation 16(12): 1257-1267.

[34] Monteiro, M. S., Santos, C., Soares, A. M. V. M., Mann, R. M. (2009): Assessment of Biomarkers of Cadmium Stress in Lettuce. - Ecotoxicology and Environmental Safety 72(3): 811-818.

[35] Nazar, R., Iqbal, N., Masood, A., Khan, M. I. R., Syeed, S., Khan, N. A. (2012): Cadmium Toxicity in Plants and Role of Mineral Nutrients in Its Alleviation. - American Journal of Plant Sciences 3: 1476-1489.

[36] Ogundele, D. T., Adio, A. A., Oludele, O. E. (2015): Heavy Metal Concentrations in Plants and Soil Along Heavy Traffic Roads in North Central Nigeria. - J. Environ. Anal. Toxicol. 5(6): 334. Doi: 10.4172/2161-0525.1000334.

[37] Pais, I., Jones, J. B. (1997): The Handbook of Trace Elements. - $1^{\text {st }}$ ed., St. Lucie Press, Boca Raton, Florida, 240p. 
[38] Pierzynski, G. M., Vance, G. F., Sims, J. T. (2005): Soils and Environmental Quality. - $3^{\text {rd }}$ ed., Crc Press. UK, 584p.

[39] Qin, S., Liu, H., Nie, Z., Rengel, Z., Gao, W., Li, C., Zhao, P. (2020): Toxicity of Cadmium and Its Competition with Mineral Nutrients for Uptake by Plants: A Review. - Pedosphere 30(2): 168-180.

[40] Ravindran, B., Mupambwa, H. A., Silwana, S., Mnkeni, P. N. (2017): Assessment of Nutrient Quality, Heavy Metals and Phytotoxic Properties of Chicken Manure on Selected Commercial Vegetable Crops. - Heliyon 3(12): E00493.

[41] Shaheen, N., Irfan, N. M., Khan, I. N., Islam, S., Islam, M. S., Ahmed, M. K. (2016): Presence of Heavy Metals in Fruits and Vegetables: Health Risk Implications in Bangladesh. - Chemosphere 152: 431-438.

[42] Smolders, E. (2001): Cadmium Uptake by Plants. - International Journal of Occupational Medicine and Environmental Health 14(2): 177-183.

[43] Sun, S., Li, M., Zuo, J., Jiang, W., Liu, D. (2015): Cadmium Effects on Mineral Accumulation, Antioxidant Defence System and Gas Exchange in Cucumber. Zemdirbyste-Agriculture 102(2): 193-200.

[44] Tan, K. H. (1995): Soil sampling, preparation, and analysis. - CRC press, Boca Raton, Florida, 623p.

[45] Ukpe, A. R., Chokor, A. A. (2018): Correlation Between Concentrations of Some Heavy Metals in Poultry Feed and Waste. - Open Access Journal of Toxicology 3(2): 555609. DOI: 10.19080/OAJT.2018.03.555609.

[46] Yang, M. G., Lin, X. Y., Yang, X. E. (1998): Impact of Cd on Growth and Nutrient Accumulation of Different Plant Species. - Chinese J. Appl. Ecol. 9: 89-94.

[47] Zhang, X., Gao, B., Xia, H. (2014): Effect of Cadmium on Growth, Photosynthesis, Mineral Nutrition and Metal Accumulation of Bana Grass and Vetiver Grass. Ecotoxicology and Environmental Safety 106: 102-108.

[48] Zhou, T., Wu, L., Luo, Y., Christie, P. (2018): Effects of Organic Matter Fraction and Compositional Changes on Distribution of Cadmium and Zinc in Long-Term Polluted Paddy Soils. - Environmental Pollution 232: 514-522. 